\title{
Histopathological Findings of Oral and Maxillofacial Biopsies from a Sample of Yemeni Patients
}

Mohammed Ali Al-Wesabi ( $\sim$ malwossabi@gmail.com ) university od sciences and technology - YEMEN

\section{Salsbeel Mohammed Al-Matari}

University of Science and Technology

Khaled Ahmed Al Jawfi

University of Science and Technology

\section{Research article}

Keywords: Biopsy, Oral mucosa, Squamous cell carcinoma of head and neck, Histopathology, Yemen Posted Date: December 10th, 2019

DOI: https://doi.org/10.21203/rs.2.18387/v1

License: (1) This work is licensed under a Creative Commons Attribution 4.0 International License. Read Full License 


\section{Abstract}

Background: Epidemiologic studies of Oral and Maxillofacial lesions (OMLs) are rare compared with the studies of caries and periodontal diseases. It is fundamental to promote early diagnosis and provide appropriate health programs. This study was to investigate the prevalence and distribution of histologically confirmed OMLs in Sana'a.

Methodology: The documented records of all patients with OMLs were recovered from the biggest histopathology laboratories that provide biopsy analysis in Sana'a Yemen, for a period of six years (2013 to 2018). This multicenter retrospective study was conducted on 1376 oral and maxillofacial biopsied lesions. The clinico-pathologic data were extracted from the histopathology reports which included age, gender, nature of specimen, site of lesion, clinical appearance and histopathological diagnosis. Descriptive analysis, Chi squared test, and binary logistic regression were performed.

Results: Regarding malignant lesions, the most prevalent lesions among males and females was squamous cell carcinoma; OSCC $(226 ; 33.0 \%$ and $214 ; 30.9 \%$; respectively). Followed by undifferentiated pleomorphic sarcoma which were five cases $(0.7 \%)$ for males and 6 cases $(0.9 \%)$ for females. Most of the cases (43.8\%) diagnosed as OSCC were in the age group older than 40 years old. At this age group, the second most prevalent lesions were Adenocarcinoma and Adenoid cystic carcinoma $(0.7 \%$ and $0.6 \%$; respectively). The results of the regression analysis show that the site of the lesion (OR; $0.6, \mathrm{Cl} ; 0.51-0.81$; $\mathrm{P}=0.00)$ and age of the patient $(\mathrm{OR} ; 4.17, \mathrm{Cl} ; 5.22-5.41 ; \mathrm{P}=0.00)$ were the independent factors of malignancy of oral lesions.

Conclusion: The present study showed high prevalence of malignant and premalignant oral mucosal lesions. The data from this study highlighted the need for dental public health intervention programs for early detection of oral cancer among Yemeni population by dental practitioners. As well as the importance of education of the general population in regards to risk factors of OMLs.

\section{Introduction}

The oral and maxillofacial region shows predilection of diverse types of alterations and lesions. Albeit an extent of oral and maxillofacial lesions (OMLs) are benign and require no dynamic treatment, some may present with significant pathology. Of specific importance are oral potentially malignant disorders (OPMDs) which may demonstrate oral epithelial dysplasia with expanding degrees of severity, tissue atrophy and/or hyperplasia [1]. Considering the high rate of malignant transformation (MT) of OPMDs, attention ought to be paid to early diagnosis [2]. Histopathologic investigation of biopsied examples is the best method to accomplish a definitive diagnosis of OMLs [3]. Moreover, studies dependent on histopathologic conclusion are more reliable[4].

The description of various oral and maxillofacial pathologies has prompted to significant differences in the nomenclature and grouping of these lesions [5]. Epidemiologic studies of OMLs are rare compared with the studies of caries and periodontal diseases [6]. Just couple of epidemiological investigations on 
the occurrence of histologically affirmed oral lesions have been directed, principally in the USA, India, some Asian countries, and Europe [7]. Surveying the distribution of OMLs in specific population is essential to understand its prevalence and characteristics, yet it is also fundamental to promote early diagnosis and provide appropriate health programs, as suggested by the World Health Organization (WHO).

In Yemen, epidemiological data directed on oral lesions are limited, and the vast majority of these data were about the relationship between khat chewing and white lesions; none of those studies had performed based on histopathological diagnosis of OMLs. Therefore, this study was to investigate the prevalence and distribution of histologically confirmed OMLs in Sana'a, Yemen and to evaluate their association with age and gender.

\section{Methodology:}

The documented records of all patients with OMLs were recovered from the biggest histopathology laboratories that provide biopsy analysis in Sana'a Yemen, for a period of 6 years (2013 to 2018). This multicenter retrospective study was conducted on 1376 oral and maxillofacial biopsied lesions after excluding all reports that were inconclusive and required immunohistochemistry for definitive diagnosis as well as those that were unsigned or without a final accommodation.

The clinico-pathological data were extracted from the histopathology reports, which included age, gender, nature of specimen, site of lesion, clinical appearance and histopathological diagnosis. The data were coded and entered as reported in the biopsy reports with some standardization using current terminologies. Lesions were grouped into either benign neoplastic lesions and malignant neoplastic lesions and further categorized based on the histopathological diagnosis into 7 broad diagnostic groups as follows: Developmental, inflammatory, reactive, cystic, premalignant, autoimmune and miscellaneous lesions.

The association of the clinical and histological factors with the gender and age categories were analyzed by chi-square test, while the factors associated with the malignancy of the lesions were analyzed using binary logistic regression. All analyses were performed at 0.05 significance value using Statistical Package for Social Science (SPSS) version 21.

\section{Results}

The total number of the analyzed biopsy reports were 1376; out of them 684 (49.7\%) males and 692 (50.3\%) females. Mean age of the study sample was 43.6 years and their age, ranging from 1 to 100 years. Regarding malignant lesions, the most prevalent lesion among males and females was OSCC (226; $33.0 \%$ and $214 ; 30.9 \%$; respectively). Followed by undifferentiated pleomorphic sarcoma which was 5 cases $(0.7 \%)$ for males and 6 cases $(0.9 \%)$ for females. Adenoid cystic carcinoma and Basal cell carcinoma were higher among females compared to male counterparts with prevalence of $(1.2 \%)$ and 
$(0.4 \%)$ and frequency of 8 cases for both lesions among females compared to 3 cases among males. Most of the cases (43.8\%) diagnosed as a OSCC were in the age group older than 40 years old. At this age group, the second most prevalent lesions were Adenocarcinoma and Adenoid cystic carcinoma $(0.7 \%$ and $0.6 \%$; respectively). Table 1 shows the distribution of malignant neoplastic lesions among the study sample according to age and gender.

Table 2 shows the distribution of benign neoplastic lesions according to the age group and gender of the patients in which fibroma, lipoma, pyogenic fibroma, capillary hemangioma and squamous papilloma were the most common lesions among males.

As OSCC was the most prevalent malignant lesion; further analysis were performed regarding tumor grade, tumor sub types, and recurrence status of the lesions. "Well differentiated" tumors, "invasive SCC" subtype, and "none recurrence" were the most among males and females, this distribution were non significantly associated with the age of the patient, (Table 3).

Distribution of the lesions was categorized into relevant groups as presented in table 4; the most common category among males and females was the malignant neoplastic lesions. Followed by benign neoplastic lesions. Whereas the least prevalence were the developmental and miscellaneous lesions, (Table 4).

The results of the regression analysis show that the site of the lesions $(\mathrm{OR} ; 0.6, \mathrm{Cl} ; 0.51-0.81 ; \mathrm{P}=0.00)$ and age of the patients $(\mathrm{OR} ; 4.17, \mathrm{Cl} ; 5.22-5.41 ; \mathrm{P}=0.00)$ were the independent factors of malignancy of oral lesions, (Table 5).

The site of the lesions in the tongue was significantly associated with their malignancy, as shown in table 6 at the malignant tongue lesions were the more prevalent at the anterior and lateral tongue, $(69.2 \%$ and $60.9 \%$; respectively). The association between site of the tongue lesions and malignancy was significant.

\section{Figure 1 presents the distribution of the lesions according to the site of biopsy as reported in the histopathological reports.}

\section{Discussion}

Understanding the distribution, prevalence and risk factors of oral and maxillofacial lesions is essential to promote primary prevention, early diagnosis, promote treatment and the provision of appropriate health services.[1]

Biopsies are considered the golden standard for the definitive diagnosis of oral and perioral lesions, and are one of the diagnostic methods that routinely performed in the medical laboratories. By the histopathological reports we can assess the prevalence of OMLs in a specific population and determine the rate of utilization of biopsy diagnostic procedures and their challenges.[8] 
Performing incisional and excisional biopsies is one of the responsibilities of general practitioners and specialists whenever indicated. The aim of the present study was to provide an important baseline data on the profile of OMLs in the capital of the republic, which will help the healthcare authorities in health planning, providing dental services, risk management, and prevention.

This study included 1376 biopsy reports from referral laboratories in the capital of the country; this increases the representativeness of the sample and generalizability of the results. Female patients predominance in this study were higher $(50.3 \%)$ compared to their male counterparts. This also the finding of many other studies.[7, 9, 10] However, other studies reported higher prevalence rate among males.[11, 12]

The mean age of the patients with OMLs was 43.6; this in accordance with that of other study among neighbor Saudi population. [5] Most of the reports were of patients their age from $4^{\text {th }}-6^{\text {th }}$ decade of age. This finding is in consistent with previous prevalence studies.[7, 13, 14] This age group is labile to be affected by other health problems leading them to seek the health care while which the oral lesions might accidently found by health care providers.

The rate of malignant neoplastic lesions in this study (36.8\%) was much higher than previously reported prevalence among other populations that represented $5.4 \%, 6.5 \%, 1.9 \%, 2.4 \%$ and $5.8 \%$ respectively. [7, 15-17] Surprisingly, studies from south western region of Saudi Arabia reported a higher incidence of malignant lesions (38.8\%) and smokeless tobacco specifically shamma was held accountable for increased incidence of malignant lesions. $[5,18]$ This higher prevalence of oral cancers might be due to the commonly practiced habits among Yemeni population such as Qat chewing, smoking, and Shamma using, [19] which can contribute to oral cancers, and also could explains the relatively equal reported prevalence of malignant lesions among the presents study sample and that of Saudi study.

When compared to premalignant lesions, malignant neoplastic lesions was much higher $(n=90 ; 6.5 \%$ and $36.8 \%$; respectively). This is an agreement with other authors, $[5,7,13]$ and this suggests failure of early detection of suspicious oral lesions by oral health care providers, delay of case referral from general or specialized dental practitioners to biopsy the lesions or patients being unaware of oral malignant lesions and not seeking treatment in absence of the pain.

OSCC was the most predominant malignant (86.7\%), this finding is nearly similar to that of the neighboring Saudi population study which reported prevalence of 93.1\%. [5] Other studies in Arab region reported percentages in the same range such as Jordon (84\%), [20] and UAE (77\%). [21] OSSC also more prevalent among older age group of the present study sample; this is in the line with other previous studies.[11,22] Higher incidence of OSCC in the present study might be due to that most of the patients came to the doctors at late stage of oral lesions when most of the premalignant lesions has undergone malignancy transformation. Furthermore, common bad habits mentioned before play an important role. On the other hand; studies from other populations reported much lower incidence of OSCC; Spain, 1.4\%; [23] Brazil, 2.5\%;[24] and Nigeria, 10.8\%. [25] 
Men to women ratio of OSCC patients in the current study was 1:1.5;comparable result was reported in previous study [5]which stated a ratio of 1:1.9. The ratio of benign to malignant lesions in this study was relatively equal 0.8: 1 ; this finding is greatly differ from that of other Saudi study which reported a ratio of $1: 4.5$, and British study that reported a value of $1: 5$. This might be explained by the difference in the level of awareness among the patients in the different countries as well as the differences in the health care facilities and utilization of these services by the population.

Cystic lesions were the fifth most common oral and maxillofacial lesions in this study. Also, lesions related to immune-mediated diseases were observed in 13 specimens (1.9\%) and more common in male patients (1.2\%). These results are varied from that a recent study stated that cystic lesions were the second most common and lesions related to immune-mediated diseases were observed in 60 specimens (4.9\%) with more predilection in female patients. [7] This might be owing to the different populations and consequently different social sociodemographic characteristics.

From the benign neoplastic lesions, fibroma was the most prevalent lesion in the present study sample (n $=98 ; 7.1 \%)$. This finding is in concordant with other studies. $[7,26]$ However, another study reported a lower percentage among its population 4.5\%.[27] Fibromas are mostly non-painful lesions that caused by many etiologies, and since it is an exophytic lesions that commonly cause discomfort in the oral cavity for which the patients seek a treatment.

This study shows that squamous papilloma represented $3.2 \%$ of oral and maxillofacial lesions. This finding is higher than that of previous studies. $[15,28]$ Pyogenic granuloma was the second most common benign neoplastic lesion ( $n=73,5.3 \%$ ) with higher prevalence among the younger age group of 40 years or less. This result is in agreement with other studies.[29, 30] Nevertheless, the relatively high prevalence of pyogenic granuloma suggests that difficulty in maintaining oral hygiene in children and adolescents is the main etiological factor involved in the development of pyogenic granuloma.

Among salivary gland lesions, adenoid cystic carcinoma was the most common lesion. Many other studies were reported the same finding. $[7,13,31]$ However, another study was reported that mucocele was the most common lesion of salivary glands. [32] This difference might be related to varying in the study populations and their social habits.

In a recent study which performed among a sample of 409 Yemeni patients in Sana'a city, authors found premalignant lesions were not common in their study. [33] Contrarily, premalignant lesions represented the fourth most common category of oral and maxillofacial lesions in the present study $(n=90 ; 6.5 \%)$. This disagreement of the results in the same population is questionable and it might be due to differences in data collection methods and sampling technique. Moreover, the previous study sample was from the dental polyclinics of faculty of dentistry to which the patients came seeking specific dental treatment for usually milder compliances. Whereas the present study sample was more representative, including the main histopathological laboratories throughout the capital of the country. 
In the current study, the tongue was the most affected site of oral neoplastic lesions (38.4\%). A similar results had been reported in Yemen $[19,34]$ and most of the developed and developing countries. [21, 35, 36] So it is considered as one of the high risk area for development of oral neoplastic lesions. This also agreed that reported I the main textbooks of oral medicine.

The results of the present study show that most of OSCC were diagnosed at advanced stages. The same finding was reported in an earlier study in Yemen, [34] this finding might be related to lower oral health knowledge and behaviors among Yemeni patients. Moreover, other authors among different populations reported similar results. [37, 38] On the other hand, high proportion of OSCC cases in the developed countries were diagnosed at early stages. $[39,40]$

In this study, well and moderately differentiated OSCC accounted for $86.1 \%$ of the reported cases. Comparable results were reported in other studies.[34, 35] Contrarily, Effiom et al reported a much higher proportion of poorly differentiated OSCC (47\%) in Nigeria. [41]This difference may be due to the different prevalence of the risk factors worldwide and intensity of exposure to these factors or both. The role of genetic factors was suggested too. [42]

Tumor staging and histopathological grading systems are good predictors of the prognosis and survival. OSCC in Yemeni young patients might be a different sort of cancer with worse prognosis as tumor staging and histopathological grading are slightly worse compared to OSCC in Yemeni old patients, this finding supports that of Halboub's study. Contrarily, previous studies reported that there are no specific clinical or histopathological features of OSCC in young adults. [38, 39]

Although the increased number of dental faculties and graduated dentists, there is a limited access and utilization of oral health services in Yemen, particularly in rural areas. Clearly, governorates with wellfacilitated healthcare centers, acceptable socioeconomic status, highly educated community increases the patients access to health services. [43] These aspects apparently generate inequalities that modify the oral health profiles of rural populations. In addition, general medical and dental practitioners need better training in the diagnosis of oral conditions. The lack of skills in oral mucosal lesions detection and oral diagnostic process probably contributes to the underestimation of lesions prevalence. The data from this study highlight the importance of education in oral health promotion for health professionals and the general population. These activities should be included in oral premalignant and malignant lesions screening campaigns to improve their effectiveness.

\section{Conclusion}

Conclusion: The present study showed high prevalence of malignant and premalignant oral mucosal lesions. This finding emphasize the necessity of intensive oral public health program in this region, for early detection and effective prevention. Furthermore, risk factors and social habits associated with malignant lesions among Yemeni population in particular should be assessed. 


\section{Declarations}

Acknowledgements:

The authors thanks all the laboratories from which the histopathology reports were gathered (National Center of Public Health Laboratories, Al Ma'amon medical Labs, UST Hospital, ILAB Labs, Al -Aualqi Medical Labs, Modern International Labs, and NEWLAB Labs). Thanks also for Dr. Wael Al- Absi, Pathologist and Dr. Zead, Head of pathology dept. in the National Center of Public Health Laboratories, for their collaboration.

\section{Authors' contributions:}

MA performed the statistical analysis and interpretation, and was the major contributor in writing the manuscript. SM conceived of the study, collected the sample data, entered the data to SPSS, and participated in the draft and writing of the manuscript. KA participated in the draft and writing of the manuscript. All authors have read and approved the final manuscript.

\section{Funding:}

None.

\section{Availability of data and materials:}

The datasets generated and/or analysed during the current study are available from the corresponding author on reasonable request.

\section{Ethics approval and consent to participate:}

This cross-sectional study was performed in accordance with the Declaration of Helsinki, ethical approval was gained from the Ethical Committee of Faculty of Medicine, University of Science and Technology, Yemen, (Approval no. EAC/UST173). As the data were retrospectively gained; patients consent is an applicable, permission from each source of data, which were mostly medical labs, was gained from each, with the condition that the data will be anonymously manipulated for the patient and for the data source too.

\section{Consent for publication:}

Not applicable.

\section{Competing interests:}

The authors declare that there are no competing interests in this study.

\section{Abbreviations}


OSCC Oral Squamous cell carcinoma

OMLs Oral and Maxillofacial lesions

OPMDs Oral Potentially Malignant Disorders

\section{References}

1. Feng J, Zhou Z, Shen X, Wang Y, Shi L, Wang Y, Hu Y, Sun H, Liu W: Prevalence and distribution of oral mucosal lesions: a cross-sectional study in S hanghai, $\mathrm{C}$ hina. Journal of Oral Pathology \& Medicine 2015, 44(7):490-494.

2. Bhatia N, Lalla Y, Vu AN, Farah CS: Advances in optical adjunctive AIDS for visualisation and detection of oral malignant and potentially malignant lesions. International journal of dentistry 2013 , 2013.

3. de Vasconcelos Carvalho M, Iglesias DPP, do Nascimento GJF, Sobral APV: Epidemiological study of 534 biopsies of oral mucosal lesions in elderly Brazilian patients. Gerodontology 2011, 28(2):111115.

4. Pardis S, Taheri MM, Fani MM: Oraland Maxillofacial Lesions in an Elderly Population in Shiraz, Iran. 2014.

5. Saleh SM, Idris AM, Vani NV, Tubaigy FM, Alharbi FA, Sharwani AA, Mikhail NT, Warnakulasuriya S: Retrospective analysis of biopsied oral and maxillofacial lesions in south-western Saudi Arabia. Saudi medical journal 2017, 38(4):405.

6. Al-Mobeeriek A, AIDosari AM: Prevalence of oral lesions among Saudi dental patients. Annals of Saudi medicine 2009, 29(5):365-368.

7. Alhindi NA, Sindi AM, Binmadi NO, Elias WY: A retrospective study of oral and maxillofacial pathology lesions diagnosed at the Faculty of Dentistry, King Abdulaziz University. Clinical, cosmetic and investigational dentistry 2019, 11:45.

8. Akinyamoju AO, Adeyemi BF, Adisa AO, Okoli CN: Audit of oral histopathology service at a Nigerian tertiary institution over a 24-year period. Ethiopian journal of health sciences 2017, 27(4):383-392.

9. Sixto-Requeijo R, Diniz-Freitas M, Torreira-Lorenzo J-C, García-García A, Gándara-Rey JM: An analysis of oral biopsies extracted from 1995 to 2009 , in an oral medicine and surgery unit in Galicia (Spain). Medicina oral, patologia oral y cirugia buca/2012, 17(1):e16.

10. Moridani SG, Shaahsavari F, Adeli MB: A 7-year retrospective study of biopsied oral lesions in $\mathbf{4 6 0}$ Iranian patients. RSBO Revista Sul-Brasileira de Odontologia 2014, 11(2):118-124.

11. Luqman M, AZ AS: A 3 year study on the Clinico-Pathological attributes of Oral lesions in Saudi Patients. International Journal of contemporary Dentistry 2012, 3(1).

12. Qannam A, Bello IO: The range of diagnoses for oral soft-tissue biopsies of geriatric patients in a Saudi Arabian teaching hospital. The Saudi dental journal 2016, 28(2):96-101. 
13. ALANAZI YM, ALRWUILI MR, Latif K, ALENZI NA, ALENZI BA, ALJABAB MA: A 5-YEARS RETROSPECTIVE STUDY OF ORAL PATHOLOGICAL LESIONS IN 425 SAUDI PATIENTS. Pakistan Oral \& Dental Journal 2016, 36(1).

14. Saravani S, Moudi M, Kadeh H, Tavakoli Amin M: Epidemiological Study of Oral and Maxillofacial Biopsies from Geriatric Patients in Zahedan, Iran (1996-2015). Journal of Dental Materials and Techniques 2016, 5(4):202-207.

15. Jones A, Franklin C: An analysis of oral and maxillofacial pathology found in adults over a 30-year period. Journal of oral pathology \& medicine 2006, 35(7):392-401.

16. Ali M, Sundaram D: Biopsied oral soft tissue lesions in Kuwait: a six-year retrospective analysis. Medical Principles and Practice 2012, 21(6):569-575.

17. Mendez M, Carrard VC, Haas AN, Lauxen IdS, Barbachan JJD, Rados PV, Sant'Ana Filho M: A 10-year study of specimens submitted to oral pathology laboratory analysis: lesion occurrence and demographic features. Brazilian oral research 2012, 26(3):235-241.

18. Vani NV, Idris AM, Saleh SM, Tubaigy FM, Alharbi FA, Sharwani AA, Tadrus N, Warnakulasuriya S: Retrospective analysis of benign orofacial tumors at a tertiary referral center in Saudi Arabia. Journal of investigative and clinical dentistry 2017, 8(4):e12254.

19. Sawair FA, Al-Mutwakel A, Al-Eryani K, Al-Surhy A, Maruyama S, Cheng J, Al-Sharabi A, Saku T: High relative frequency of oral squamous cell carcinoma in Yemen: qat and tobacco chewing as its aetiological background. International journal of environmental health research 2007, 17(3):185-195.

20. Rawashdeh M, Matalka I: Malignant oral tumors in Jordanians, 1991-2001. A descriptive epidemiological study. International journal of oral and maxillofacial surgery 2004, 33(2):183-188.

21. Anis R, Gaballah K: Oral cancer in the UAE: a multicenter, retrospective study. Libyan Journal of Medicine 2013, 8(1):21782.

22. Patil S, Doni B, Maheshwari S: Prevalence and distribution of oral mucosal lesions in a geriatric Indian population. Canadian Geriatrics Journal 2015, 18(1):11.

23. Fierro-Garibay C, Almendros-Marqués N, Berini-Aytés L, Gay-Escoda C: Prevalence of biopsied oral lesions in a Department of Oral Surgery. J Clin Exp Dent 2011, 3(2):e73-77.

24. Marocchio LS, Lima J, Sperandio FF, Corrêa L, de Sousa SO: Oral squamous cell carcinoma: an analysis of 1,564 cases showing advances in early detection. Journal of oral science 2010, 52(2):267-273.

25. Ajayi O, Adeyemo W, Ladeinde A, Ogunlewe M, Effiom O, Omitola O, Arotiba G: Primary malignant neoplasms of orofacial origin: a retrospective review of 256 cases in a Nigerian tertiary hospital. International journal of oral and maxillofacial surgery 2007, 36(5):403-408.

26. Rivera C, Droguett D, Arenas-Márquez M-J: Oral mucosal lesions in a Chilean elderly population: $A$ retrospective study with a systematic review from thirteen countries. Journal of clinical and experimental dentistry 2017, 9(2):e276.

27. El Toum S, Cassia A, Bouchi N, Kassab I: Prevalence and Distribution of Oral Mucosal Lesions by Sex and Age Categories: A Retrospective Study of Patients Attending Lebanese School of Dentistry. 
International journal of dentistry 2018, 2018.

28. Sharma BP, Baral R: Orodental biopsies in females: a 23 year study. Nepal Journal of Obstetrics and Gynaecology 2016, 11(1):24-25.

29. Martins-Filho PRS, de Santana Santos T, Piva MR, da Silva HF, da Silva LCF, Mascarenhas-Oliveira AC, de Souza A, Sávio E: A multicenter retrospective cohort study on pediatric oral lesions. Journal of Dentistry for Children 2015, 82(2):84-90.

30. Hong CH, Dean DR, Hull K, Hu SJ, Sim YF, Nadeau C, Gonçalves S, Lodi G, Hodgson TA: World Workshop on Oral Medicine VII: Relative frequency of oral mucosal lesions in children, a scoping review. Oral diseases 2019, 25:193-203.

31. Rahman NA: Oral and maxillofacial pathologic lesion: retrospective studies on prevalence and sociodemographic features. Arch Orofac Sci 2014, 9:65-75.

32. Xavier Santos RL, da Silva Júnior EZ, Aroucha Lyra MC, de Andrade R, Alonso R, Vilela Heimer M, de Souza Andrade ES: Oral and maxillofacial lesions in children and adolescents. Revista Cubana de Estomatología 2018, 55(4):1-9.

33. Al-Maweri SA, Alaizari NA, Al-Sufyani GA: Oral mucosal lesions and their association with tobacco use and qat chewing among Yemeni dental patients. Journal of clinical and experimental dentistry 2014, 6(5):e460.

34. Halboub E, Al-Mohaya M, Abdulhuq M, Al-Mandili A, Al-Anazi Y: Oral squamous cell carcinoma among Yemenis: onset in young age and presentation at advanced stage. Journal of clinical and experimental dentistry 2012, 4(4):e221.

35. Pires FR, Ramos AB, Oliveira JBCd, Tavares AS, Luz PSRd, Santos TCRBd: Oral squamous cell carcinoma: clinicopathological features from 346 cases from a single oral pathology service during an 8-year period. Journal of Applied Oral Science 2013, 21(5):460-467.

36. Miyake Y, Shinozuka K, Ueki K, Teraoka J, Zama M, Ogisawa S, Shinozaki Y, Aoki J, Yanagawa K, Shimizu O: Retrospective clinical study of $\mathbf{2 9 6}$ patients with mass lesions of the tongue. Journal of oral science 2018, 60(4):574-578.

37. Sargeran K, Murtomaa H, Safavi SMR, Vehkalahti M, Teronen O: Malignant oral tumors in Iran: tenyear analysis on patient and tumor characteristics of 1042 patients in Tehran. Journal of Craniofacial Surgery 2006, 17(6):1230-1233.

38. Ribeiro ACP, Silva ARS, Simonato LE, Salzedas LMP, Sundefeld MLMM, Soubhia AMP: Clinical and histopathological analysis of oral squamous cell carcinoma in young people: a descriptive study in Brazilians. British Journal of Oral and Maxillofacial Surgery 2009, 47(2):95-98.

39. Sasaki T, Moles D, Imai Y, Speight P: Clinico-pathological features of squamous cell carcinoma of the oral cavity in patients 40 years of age. Journal of oral pathology \& medicine 2005, 34(3):129-133.

40. Han S, Chen Y, Ge X, Zhang M, Wang J, Zhao Q, He J, Wang Z: Epidemiology and cost analysis for patients with oral cancer in a university hospital in China. BMC public health 2010, 10(1):196.

41. Effiom OA, Adeyemo WL, Omitola OG, Ajayi OF, Emmanuel MM, Gbotolorun OM: Oral squamous cell carcinoma: a clinicopathologic review of 233 cases in Lagos, Nigeria. Journal of Oral and 
Maxillofacial Surgery 2008, 66(8):1595-1599.

42. Siriwardena B, Tilakaratne A, Amaratunga E, Udagama M, Ogawa I, Kudo Y, Takata T, Tilakaratne W: Analysis of histopathological and immunohistochemical differences of oral squamous cell carcinoma in young and old patients in Sri Lanka. Journal of oral pathology \& medicine 2007, 36(6):357-362.

43. Gheno JN, Martins MAT, Munerato MC, Hugo FN, SANT'ANA FILHO M, Weissheimer C, Carrard VC, Martins MD: Oral mucosal lesions and their association with sociodemographic, behavioral, and health status factors. Brazilian oral research 2015, 29(1):1-6.

\section{Tables}

Table 1. Malignant neoplastic lesions of the study samples according to age and gender.

Diagnosis

\begin{tabular}{|c|c|c|c|c|c|c|c|}
\hline \multicolumn{4}{|c|}{ Sex of patient } & \multicolumn{4}{|c|}{ Age group } \\
\hline \multicolumn{2}{|c|}{$\begin{array}{c}\text { Male } \\
(\mathrm{n}=684)\end{array}$} & \multicolumn{2}{|c|}{$\begin{array}{l}\text { Female } \\
(\mathrm{n}=692)\end{array}$} & \multicolumn{2}{|c|}{$\begin{array}{l}40 \text { years or } \\
\text { less }(n=532)\end{array}$} & \multicolumn{2}{|c|}{$\begin{array}{l}>40 \text { years } \\
\text { old }(n=844)\end{array}$} \\
\hline $\mathrm{F}$ & $\%$ & $\mathrm{~F}$ & $\%$ & $\mathrm{~F}$ & $\%$ & $\mathrm{~F}$ & $\%$ \\
\hline 0 & 0.0 & 6 & 0.9 & 0 & 0.0 & 6 & 0.7 \\
\hline 3 & 0.4 & 8 & 1.2 & 6 & 1.1 & 5 & 0.6 \\
\hline 2 & 0.3 & 0 & 0.0 & 2 & 0.4 & 0 & 0.0 \\
\hline 3 & 0.4 & 8 & 1.2 & 1 & 0.2 & 10 & 1.2 \\
\hline 1 & 0.1 & 0 & 0.0 & 0 & 0.0 & 1 & 0.1 \\
\hline 2 & 0.3 & 0 & 0.0 & 0 & 0.0 & 2 & 0.2 \\
\hline 2 & 0.3 & 0 & 0.0 & 2 & 0.4 & 0 & 0.0 \\
\hline 2 & 0.3 & 0 & 0.0 & 2 & 0.4 & 0 & 0.0 \\
\hline 0 & 0.0 & 1 & 0.1 & 1 & 0.2 & 0 & 0.0 \\
\hline 0 & 0.0 & 1 & 0.1 & 1 & 0.2 & 0 & 0.0 \\
\hline 8 & 1.2 & 7 & 1.0 & 3 & 0.6 & 12 & 1.4 \\
\hline 0 & 0.0 & 1 & 0.1 & 0 & 0.0 & 1 & 0.1 \\
\hline 0 & 0.0 & 1 & 0.1 & 1 & 0.2 & 0 & 0.0 \\
\hline 226 & 33.0 & 214 & 30.9 & 70 & 13.2 & 370 & 43.8 \\
\hline 5 & 0.7 & 6 & 0.9 & 8 & 1.5 & 3 & 0.4 \\
\hline
\end{tabular}

Table 2. Benign neoplastic lesions of the study samples according to age and gender. 


\begin{tabular}{|c|c|c|c|c|c|c|c|c|}
\hline & \multicolumn{2}{|c|}{$\begin{array}{c}\text { Male } \\
(\mathrm{n}=684)\end{array}$} & \multicolumn{2}{|c|}{$\begin{array}{l}\text { Female } \\
(\mathrm{n}=692)\end{array}$} & \multicolumn{2}{|c|}{$\begin{array}{l}40 \text { years or } \\
\text { less }(n=532)\end{array}$} & \multicolumn{2}{|c|}{$\begin{array}{l}>40 \text { years } \\
\text { old }(n=844)\end{array}$} \\
\hline & $\bar{F}$ & $\%$ & $\mathrm{~F}$ & $\%$ & $\mathrm{~F}$ & $\%$ & $\mathrm{~F}$ & $\%$ \\
\hline Ameloblastic fibroma & $\overline{1}$ & 0.1 & 1 & 0.1 & 1 & 0.2 & 1 & 0.1 \\
\hline Ameloblastoma & 4 & 0.6 & 2 & 0.3 & 2 & 0.4 & 4 & 0.5 \\
\hline Angiolipoma & 2 & 0.3 & 4 & 0.6 & 3 & 0.6 & 3 & 0.4 \\
\hline $\begin{array}{l}\text { Benign dermal melanocytic } \\
\text { nevus }\end{array}$ & 0 & 0.0 & 3 & 0.4 & 3 & 0.6 & 0 & 0.0 \\
\hline Capillary hemangioma & 25 & 3.7 & 22 & 3.2 & 31 & 5.8 & 16 & 1.9 \\
\hline Cartilaginous choristoma & 0 & 0.0 & 2 & 0.3 & 0 & 0.0 & 2 & 0.2 \\
\hline $\begin{array}{l}\text { Caseating granuloma } \mathrm{c} / \mathrm{w} \\
\text { tuberculosis }\end{array}$ & 1 & 0.1 & 6 & 0.9 & 6 & 1.1 & 1 & 0.1 \\
\hline Cavernous hemangioma & 2 & 0.3 & 14 & 2.0 & 12 & 2.3 & 4 & 0.5 \\
\hline Cemento ossifying fibroma & 0 & 0.0 & 1 & 0.1 & 1 & 0.2 & 0 & 0.0 \\
\hline Fibrolipoma & 3 & 0.4 & 3 & 0.4 & 0 & 0.0 & 6 & 0.7 \\
\hline Fibroma & 52 & 7.6 & 46 & 6.6 & 49 & 9.2 & 49 & 5.8 \\
\hline Giant cell granuloma & 9 & 1.3 & 9 & 1.3 & 10 & 1.9 & 8 & 0.9 \\
\hline Keratoacanthoma & 3 & 0.4 & 1 & 0.1 & 0 & 0.0 & 4 & 0.5 \\
\hline Lipoma & 20 & 2.9 & 26 & 3.8 & 18 & 3.4 & 28 & 3.3 \\
\hline Lymphangioma & 7 & 1.0 & 4 & 0.6 & 3 & 0.6 & 8 & 0.9 \\
\hline Melanocytic nevi & 1 & 0.1 & 1 & 0.1 & 0 & 0.0 & 2 & 0.2 \\
\hline Mesenchymal hamartoma & 2 & 0.3 & 0 & 0.0 & 2 & 0.4 & 0 & 0.0 \\
\hline Neurofibroma & 0 & 0.0 & 3 & 0.4 & 2 & 0.4 & 1 & 0.1 \\
\hline Ossifying fibroma & 3 & 0.4 & 7 & 1.0 & 3 & 0.6 & 7 & 0.8 \\
\hline Osteochondroma & 1 & 0.1 & 0 & 0.0 & 1 & 0.2 & 0 & 0.0 \\
\hline Periapical granuloma/abscess & 0 & 0.0 & 1 & 0.1 & 1 & 0.2 & 0 & 0.0 \\
\hline Plasma cell granuloma & 12 & 1.8 & 9 & 1.3 & 14 & 2.6 & 7 & 0.8 \\
\hline Pleomorphic adenoma & 1 & 0.1 & 5 & 0.7 & 4 & 0.8 & 2 & 0.2 \\
\hline Pyogenic granuloma & 39 & 5.7 & 34 & 4.9 & 46 & 8.6 & 27 & 3.2 \\
\hline Schwannoma & 3 & 0.4 & 2 & 0.3 & 5 & 0.9 & 0 & 0.0 \\
\hline Squamous papilloma & 23 & 3.4 & 21 & 3.0 & 22 & 4.1 & 22 & 2.6 \\
\hline Traumatic neuroma & 0 & 0.0 & 1 & 0.1 & 0 & 0.0 & 1 & 0.1 \\
\hline
\end{tabular}

Table 3. Association between SCC; grade, subtype, and recurrence status with the age of the patients. 
Age of the patient

\begin{tabular}{cccc}
\hline $\begin{array}{c}40 \text { years or } \\
\text { less }\end{array}$ & $\begin{array}{c}\text { More than } 40 \\
\text { years old }\end{array}$ & $\begin{array}{c}\text { P- } \\
\text { value }\end{array}$ \\
\cline { 1 - 3 } F & $\%$ & F & $\%$
\end{tabular}

\begin{tabular}{|c|c|c|c|c|c|c|}
\hline \multirow[t]{5}{*}{$\begin{array}{l}\text { Tumor } \\
\text { grade }\end{array}$} & Poor differentiated & 1 & 14 & 17 & 46 & \multirow[t]{5}{*}{.099} \\
\hline & Moderate differentiated & 24 & 34.3 & 114 & 30.8 & \\
\hline & Well differentiated & 38 & 54.3 & 203 & 54.9 & \\
\hline & Undifferentiated & 2 & 2.9 & 1 & 0.3 & \\
\hline & NM & 5 & 7.1 & 35 & 9.5 & \\
\hline \multirow{7}{*}{$\begin{array}{l}\text { Tumor } \\
\text { subtype }\end{array}$} & $\mathrm{SCC}$ & 16 & 220 & 87 & 235 & \multirow[t]{7}{*}{.637} \\
\hline & Non keratinizing SCC & 2 & 2.9 & 2 & 0.5 & \\
\hline & Keratinizing SCC & 5 & 7.1 & 33 & 8.9 & \\
\hline & Invasive SCC & 24 & 34.3 & 132 & 35.7 & \\
\hline & Invasive keratinizing SCC & 14 & 20.0 & 79 & 21.4 & \\
\hline & Metastatic SCC & 4 & 5.7 & 15 & 4.1 & \\
\hline & Verrucous SCC & 5 & 7.1 & 22 & 5.9 & \\
\hline \multirow[t]{4}{*}{ Recurrence } & & & & & & \multirow[t]{4}{*}{.202} \\
\hline & $\begin{array}{l}\text { No history of recurrence has been } \\
\text { mentioned }\end{array}$ & 59 & 84.3 & 283 & 76.5 & \\
\hline & Recurrent from the same site & 1 & 1.4 & 2 & 0.5 & \\
\hline & Recurrent from other oral site & 10 & 14.3 & 85 & 23.0 & \\
\hline
\end{tabular}

Table 4. Classification of the studied biopsies and their distribution according to gender.

\begin{tabular}{|c|c|c|c|c|c|}
\hline & \multicolumn{4}{|c|}{ Sex of patient } \\
\hline & & \multicolumn{2}{|c|}{ Male } & \multicolumn{2}{|c|}{ Female } \\
\hline & & $\mathrm{F}$ & $\%$ & $\bar{F}$ & $\%$ \\
\hline \multirow[t]{9}{*}{ Oral and maxillofacial classification } & Benign neoplastic lesions & 214 & $\overline{31.3}$ & 233 & $\overline{33.7}$ \\
\hline & Malignant neoplastic lesions & 254 & 37.1 & 253 & 36.6 \\
\hline & Developmental lesions & 1 & 0.1 & 6 & 0.9 \\
\hline & Inflammatory lesions & 107 & 15.6 & 92 & 13.3 \\
\hline & Reactive lesions & 10 & 1.5 & 19 & 2.7 \\
\hline & Cystic lesions & 40 & 5.8 & 42 & 6.1 \\
\hline & Premalignant lesions & 49 & 7.2 & 41 & 5.9 \\
\hline & Autoimmune lesions & 8 & 1.2 & 5 & 0.7 \\
\hline & Miscellaneous lesion & 1 & 0.1 & 1 & 0.1 \\
\hline
\end{tabular}

Table 5. Binary logistic regression analysis of the factors associated with the malignancy of the lesions. 
Variable Category

\begin{tabular}{|c|c|c|c|c|c|}
\hline & & $\begin{array}{l}\text { Benign } \\
(\mathrm{n}=869)\end{array}$ & $\begin{array}{l}\text { Malignant } \\
(\mathrm{n}=507)\end{array}$ & (Conndence intervals) & \\
\hline \multirow[t]{4}{*}{ Gender } & Male & 430 & 254 & $.919 \quad(0.729-1.159)$ & \multirow{4}{*}{.475} \\
\hline & $\%$ & 49.5 & 50.1 & & \\
\hline & Female & 439 & 253 & & \\
\hline & $\%$ & 50.5 & 49.9 & & \\
\hline \multirow[t]{4}{*}{$\overline{\text { Site }}$} & Tongue & 296 & 233 & $.646 \quad(0.510-.817)$ & \multirow{4}{*}{0.000} \\
\hline & $\%$ & 34.1 & 46.0 & & \\
\hline & Other sites & 573 & 274 & & \\
\hline & $\%$ & 65.9 & 54.0 & & \\
\hline \multirow[t]{4}{*}{ Age } & 40 yrs. or less & 435 & 97 & 4.178 (3.222- 5.418) & \multirow{4}{*}{0.000} \\
\hline & $\%$ & 50.1 & 19.1 & & \\
\hline & More than 40 years old & 434 & 410 & & \\
\hline & $\%$ & 49.9 & 80.9 & & \\
\hline
\end{tabular}

Table 6. Description and association between the site of the tongue lesions and their malignancy.

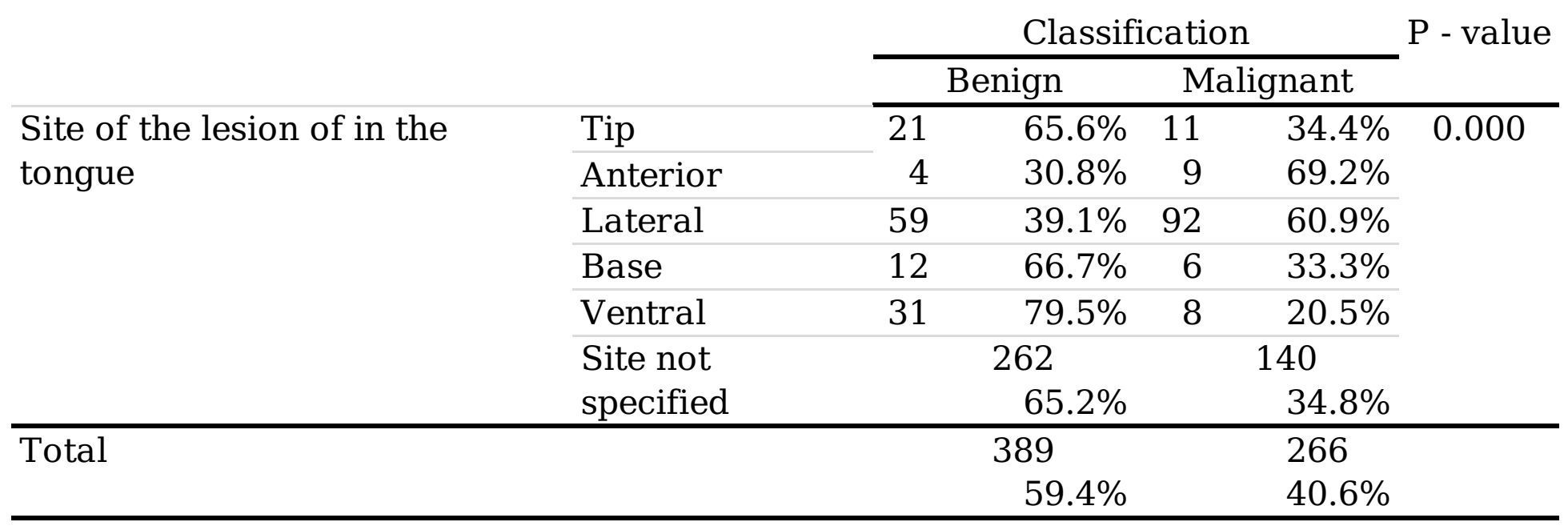

Figures 


\section{Figure 1. Distribution of the study sample according to the site of biopsy}

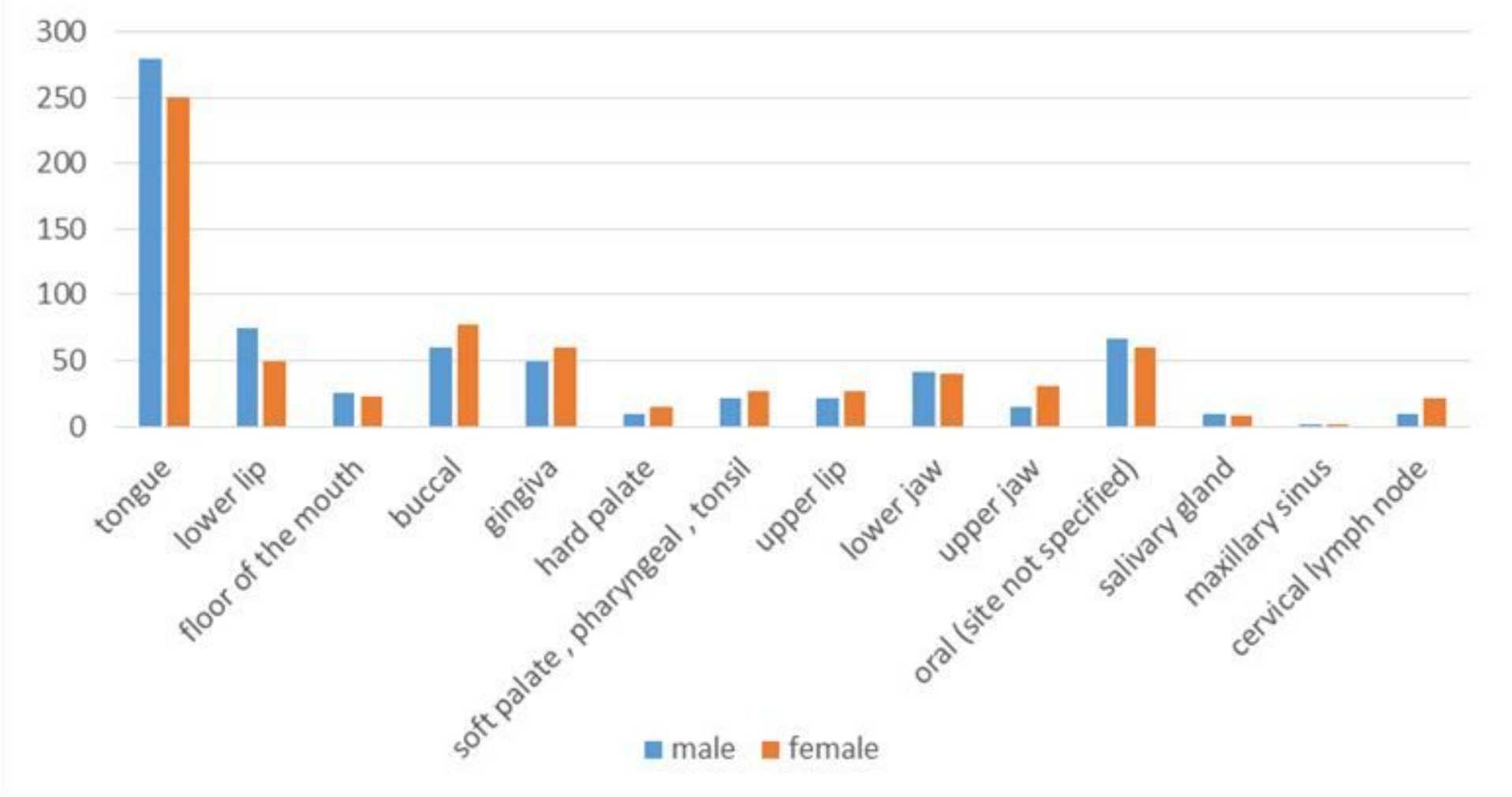

Figure 1

Presents the distribution of the lesions according to the site of biopsy as reported in the histopathological reports. 